водоемов во внутриквартальной застройке по исследований по водной токсикологии. М.: Наука, 1971. комплексу гидрохимических и гидробиологических С. 14-60. показателей на примере Самары // Экологические проблемы промышленных городов. Саратов, СГТУ, 2013. С. 304-306.

8. Жадин В.И. Методы гидробиологического исследования. М.: Высшая школа, 1960. 189 с.

9.Руководствопогидробиологическомумониторингу пресноводных экосистем. СПб.: Гидрометеоиздат, 1992. $246 \mathrm{c}$.

10. Определитель пресноводных беспозвоночных России и сопредельных территорий. Т. 1. Низшие беспозвоночные./ СПб: ЗИН, 1994. 394 с.

11. Кутикова Л.А. Коловратки фауны СССР. / Л. Наука, 1970.- 744 с.

12. Кутикова Л.А. Бделлоидные коловратки фауны России. / М.: ТНИ КМК, 2005. 315 с.

13. Шитиков В.К., Розенберг г.С., Зинченко Т.Д. Количественная гидроэкология / Тольятти: ИЭВБ РАН, 2003. $463 \mathrm{c}$

14. Строганов Н.С. Методика определения

15. Герасимов Ю.Л. Зоопланктон как компонент гидробиоценозов городских прудов // Вестник Самарского госуниверситета, 2007, №8(58). С. 39-49.

16. Васин А.Е., Герасимов Ю.Л., Дюжаева И.В. и др. Беспозвоночные в экосистеме пруда на ул.Аминева (г. Самара) в 2010 г. // Вестник Самарского госуниверситета, Ест. научн. серия, 2012, №3/2 (94). С. 45-52.

17. Мухортова О.В. Сообщества зоопланктона пелагиали и зарослей высших водных растений разнотипных водоемов средней и нижней Волги / Дисс. ... канд. биол. наук. Тольятти: ИЭВБ, 2008. 126 с.

18. Гублер Е.В. Вычислительные методы анализа и распознавания патологических процессов Л.: Медицина, 1978. 294 c.

19. Langley J.M., Kett S., Al-Khalilil R.S., Humphrey C.J. The conservation value of English urban ponds in terms of their rotifer fauna // Hydrobiologia, 1995, V. 313-314, №2. P. 259-266. токсичности водной среды // Методики биологических

\title{
INVERTEBRATES IN THE COMMUNITY OF URBAN POND NEAR NOVO-SADOVAJA STREET (SAMARA-CITY) IN 2010
}

(C) 2015

Yu.L. Gherasimov, Candidate of Biological Sciences, Chief of the Department of Zoology, Genetics and Common Ecology

Samara State University, Samara (Russia)

Annotation. The state of right pond of two nearly located small ponds in Samara-city was described. 47 Rotatoria species (26 genus, 18 familiars) was found in 2010, the list of met rotifer species is quoted. The Brachionidae, Phylodinidae and Synchaetidae have maximum species quantity. The numerity and biomass seasonal dynamics was studied. Two numerity and biomass growths (in May and August) observes in majority Rotifera populations. Brachionidae Synchaetidae had maximal numerity, Asplanchnidae and Synchaetidae have maximal biomass. The Rotatoria numerity was in twice more than in near located pond. Value of index species similarity of Serensen is equal 7,27. The Shannon and Pielu indexes was calculated. 17 water Insect species lives in pond. Crustaceans, Gastropods, Turbellaria, Nematoda, Oligochaeta and Ciliophora was founded in pond. The fish Perccottus glenii was founded too. The chemical analisis show four water characteristics was greater than LAC values. The pond water toxicity for Daphnia was studied in laboratory, the N.S.Stroganov standart method was used. The pond water didn't show negative influence for Daphnia survival and fecundity. The species numerity in studied pond is greater than in some urbanized water bodies. The pond ecosystem state is close to satisfactory.

Key words: urban pond; invertebrates; species composition; population numerity; Rotatoria; Insecta; chemical composition; water toxisity.

\section{УДК 615.37-053.2:616.233-002 \\ О РОЛИ ПЕРЕКИСНОЙ И АНТИОКСИДАНТНОЙ СИСТЕМ В ПАТОГЕНЕЗЕ БРОНХИАЛЬНОЙ ОБСТРУКЦИИ}

(C) 2015

Н.Г. Герасимова, доктор медицинских наук, профессор кафедры педиатрии Мордовский государственный университет им. Н.П.Огарева, Саранск (Россия)

Т. Б. Ахвердиева, аспирант кафедры педиатрии Мордовский государственный университет им. Н.П.Огарева, Саранск (Россия)

Ю. В. Шувалова, аспирант кафедры педиатрии Мордовский государственный университет им. Н.П.Огарева, Саранск (Россия)

Е. Н. Коваленко, кандидат биологических наук, доцент кафедры нормальной физиологии с курсом медицинской биохимии Мордовский государственный университет им. Н.П.Огарева, Саранск (Россия)

B.A. Горбатов, кандидат медицинских наук, старший преподаватель кафедры педиатрии Мордовский государственный университет им. Н.П.Огарева, Саранск (Россия)

\footnotetext{
Аннотация. Синдром бронхиальной обструкции лежит в патогенезе ряда заболеваний бронхолегочной системы, в частности рецидивирующего обструктивного бронхита и бронхиальной астмы. Изучение аспектов патогенеза этих заболеваний имеет важное значение для повышения эффективности терапии и реабилитации пациентов. У пациентов с синдромом бронхиальной обструкции отмечается дисбаланс реакций перекисного окисления липидов и системы антиоксидантной защиты со склонностью к значительному повреждению биологических мембран на клеточном и субклеточном уровне. Метаболические реакции у данных пациентов характеризуются меньшими компенсаторными возможностями, что приводит к их неконтролируемому цепному течению с развитием более тяжелых форм заболевания. Анализ исследований показал, что до начала терапии у детей с рецидивирующим обструктивным синдромом отмечалось уменьшение показателей антиоксидантной защиты (содержание церулоплазмина и каталазы в сыворотке крови) и увеличение показателей интоксикации (содержание малонового альдегида в сыворотке крови). После применения полиоксидония у детей наблюдается достоверное повышение содержание церулоплазмина и каталазы и снижение содержания малонового альдегида в сыворотке крови. Установлено, что до
} 
начала терапии отмечалось увеличение показателя интоксикации (оксида азота), после применения иммуномодулятора наблюдалось достоверное снижение данного биохимического показателя в сыворотке крови у пациентов.

Ключевые слова: бронхообструктивный синдром; бронхиальная астма; рецидивирующий бронхит; перекисное окисление липидов; антиоксидантная защита; пациенты; терапия; биохимические показатели.

Бронхобструктивный синдром в детском возрасте принадлежит к числу наиболее распространенных патологий среди всех заболеваний респираторного тракта $[1,2,3$, с. 15-16]. В последнее десятилетие неуклоннонаблюдаетсяростдиспансернойгруппы«часто болеющих детей» (ЧБД), в которой рецидивирующие бронхиты являются одной из ведущих нозологических форм, нередко являясь дебютом хронических бронхолегочных заболевания [4,5,6,c.25 - 26].

Возникновение обострений бронхиальной обструкции обуславливается бронхоспазмом, отеком слизистой оболочки бронхов, скоплением мокроты в просвете бронхов, обсуждаются различные патофизиологические механизмы развития на клеточном и молекулярном уровне, в том числе механизмы антиоксидантной системы, маркеры структурнофункционального состояния эндотелия, показатели интоксикации [7,8, с. 26-28]. Среди ведущих триггерных факторов развития обострений данного синдрома у детей является острые респираторные вирусные и бактериальные инфекции [9, с. 28]. Для повышения защитных сил организма предлагаются различные методы лечения, оказывающие регулирующее влияние на различные звенья иммунитета $[10,11,12$, с. $40-41]$.

В настоящее время бронхиальную астму у детей рассматривают как аллергическое заболевание, в основе которого лежит особое иммунное воспаление дыхательных путей [13, с. 34]. Отмечаемое при обострении болезни нарушение дыхания с резко затрудненным выдохом сопровождается приступами удушья, одышкой, свистящими хрипами, кашлем, образованием мокроты. Выраженность симптомов болезни зависит от степени ее тяжести. Обструкция бронхов является обратимой спонтанно илиподвлиянием лечения. Установлено, что свободнорадикальные процессы играют существенную роль в патогенезе различных форм бронхиальной астмы. Активные формы кислорода (АФК) в силу высокой токсичности могут участвовать в первичных процессах запуска БА. Они не только способствуют развитию оксидативного стресса, инициирующего бронхоспастическим синдромом, но и приводят к хронизации воспалительного процесса в бронхах и легких $[14$, с. 87$]$.

ИзбытокАФК патологическивоздействуют налегкие, обусловливая основные клинические проявления: воспаление, нарушение функции внешнего дыхания, вторичную эмфизему. Это связано с тем, что свободные радикалы быстро реагируют с ненасыщенными липидами мембран, способствуя образованию липидных перекисей, и окисляют восприимчивые группы белков и нуклеиновых кислот [14, с. 86].

Патологические последствия оксидантного стресса, как показали морфологические исследования легочной ткани, связаны с гипертрофией и гиперплазией альвеолоцитов II типа, интерстициальным отеком, гиперплазией интерстициальных клеток, разрушением легочных капилляров. В то же время неинтенсивная реакция лейкоцитов на бактериальный агент может привести к персистенции его в организме, накоплению липидных медиаторов воспаления и хронизации процесса. Контроль за интенсивностью и продолжительностью свободнорадикальной реакции осуществляет система антиоксидантной защиты (AO3). Эта система включает ферменты (каталаза, пероксидаза, супероксиддисмутаза), неферментные компоненты (трансферрин, высокомолекулярные низкомолекулярные компоненты (витамины А, Е, С, глутатион) [14, с. 88$]$.

В лечении БА используют ингаляционные глюкокортикостероиды(ИГКС), глюкокортикостероиды для системного применения, антилейкотриеновые препараты, анти-IgE антитела, $\beta 2$-агонисты длительного действия (сальмотерол, формотерол), теофиллины $[15$, c. 100$]$.

Дополнительную группу при лечении астмы составляют препараты, обладающие иммуномодулирующим и антиоксидантным действиями. При их использовании в комплексе с базисной терапией отмечается прекращение (уменьшение) числа приступов, улучшение качества жизни (уменьшение ночных эквивалентов БА, повышение работоспособности), сокращение потребности в симпатомиметиках $[16,17,18$, с.202]. Снижается уровень продуктов перекисного окисления липидов (ПОЛ), повышается активность ферментов антиоксидантной защиты [19,20, с. 67].

Одной из задач нашей работы было исследование биохимических показателей антиоксидантной защиты и продуктов ПОЛ у детей с бронхиальной астмой до и после лечения стандартной терапией и полиоксидонием. С этой целью проведено исследование сыворотки крови у детей с бронхиальной астмой $(\mathrm{n}=15)$ и рецидивирующим бронхитом $(\mathrm{n}=15)$ на содержание церулоплазмина, малонового альдегида и каталазы. Возраст детей-от 5-ти до 15-и лет. В качестве контроля исследована сыворотка крови практически здоровых детей того же возраста $(\mathrm{n}=15)$.

Определение малонового диальдегида в сыворотке крови оценивали в реакции с 2-тиобарбитуровой кислотой (ТБК) в кислой среде при высокой температуре. В пробирки вносили реактивы по таблице 1

Определение малонового диальдегида

\begin{tabular}{|c|c|c|}
\hline & Холостая проба, мл & Опытная проба, мл \\
\hline Ортофосфорная кислота & 3,00 & 3,00 \\
\hline Сыворотка крови & - & 0,25 \\
\hline Дистиллированная вода & 0,25 & - \\
\hline Pactвop TБK & 1,00 & 1,00 \\
\hline \multicolumn{3}{|c|}{$\begin{array}{l}\text { Пробирки накрывают конденсирующиими колпачками и помещают в водяную баню на } 45 \text { минут прт } \\
100^{\circ} \text { C. После кипячения пробирки охлаждают в холодной воде } 3-5 \text { минут. }\end{array}$} \\
\hline n-Бутанол & 4,00 & 4,00 \\
\hline
\end{tabular}

Пробирки интенсивно встряхивали до образования однородной белой суспензии, имеющей розовый оттенок. Затем пробирки центрифугировали 10 минут при 3000 об/мин. Сразу после центрифугирования отбирали 3 мл супернатанта в чистую пробирку и измеряли оптическую плотность опытной пробы против холостой пробы при $\lambda=535$ нм и $\lambda=570$ нм в кювете толщиной 10 мм. Измерение проводили не позднее 1,5 ч после центрифугирования (Габриэлян Н.Г., Королюк М.А., 1988).
Расчет
проводили

$\mathrm{C}=(\mathrm{D} 535-\mathrm{D} 570) / 0,156 \cdot 16$, где

C-содержание ТБК-активных продуктов в опытной пробе мкмоль/л;

D535-оптическая плотность опытной пробы при $\lambda=535 \mathrm{HM}$;

D570-оптическая плотность опытной пробы при $\lambda=570$ нм;

0,156-коэффициент молярной экстинкции комплекса малоновый диальдегид-ТБК в л/мкмоль/см;

16-коэффициент разведения сыворотки.

Определение уровня церулоплазмина в сыворотке крови проводили по методу Равина (1956 г.), основанному на окислении р-фенилендиамина. По 
оптической плотности образующихся продуктов судили о концентрации церулоплазмина. После инкубации сыворотки крови в течение 1 часа при температуре +37 o С с 1 мл раствора р-фенилендиамина добавляли 2 мл раствора фтористого натрия и выдерживали в течение 30 минут при температуре +4o С. Пробы колориметрировали в кюветах шириной слоя $10 \mathrm{Mм}$ при зеленом светофильтре при длине волны 530 нм на фотометре КФК-3-01-«ЗОМЗ». Значение оптической плотности умножали на коэффициент пересчета 87,5 и получали величину концентрации церулоплазмина в мг\%.

Определение активности каталазы в сыворотке крови проводили фотометрическим методом. Принцип метода основан на реакции перекиси водорода с молибденовокислым аммонием в неокрашенных или слабоокрашенных растворах. К 0,1 мл сыворотки добавляли 2 мл 0,03\% раствора перекиси водорода и инкубировали 10 минут при комнатной температуре. В холостую пробу вместо сыворотки крови вносят 0,1 мл дистиллированной воды. Реакцию останавливали, добавляя 1 мл 4\% раствора молибденовокислого аммония. После центрифугирования при 3000 об/мин в течение 30 минут пробы колориметрировали в кюветах шириной слоя 10 мм при зеленом светофильтре при $\lambda=410$ нм против контрольной пробы, в которую вместо перекиси водорода вносят 2 мл дистиллированной воды.

Об уровне содержания оксида азота в крови судили по содержанию нитрит-иона, для определения которого использовали реактив Грисса, состоящий из $\mathrm{N}$-нафтилэтилендиаминдигидрохлорид $(12,5$ мМ) и сульфаниловой кислоты $(37,5 \mathrm{MM})$ в равных соотношениях (Guevara E. et al., 1998). Пробирки с кровью центрифугировали в течение 10 минут. Далее надосадосадочную жидкость добавляли к реактиву Грисса в соотношении 1:9. Содержание оксида азота определяли спектрофотометрически.

Полученные данные показали, что у больных детей с бронхиальной астмой в период обострения содержание церулоплазмина в сыворотке крови составило $15,9 \pm 0,8 \mathrm{M \Gamma} \%$, содержание каталазы в сыворотке крови до лечения составило $0,8 \pm 0,1$ мккатал /л $(\mathrm{p}<0,05)$, что ниже чем у здоровых детей, содержание малонового альдегида до лечения 5,4 $\pm 0,3$ мкмоль/л, что достоверно выше, чем у здоровых детей. После проведенного лечения содержание церулоплазмина и активность

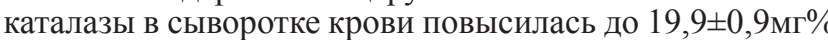
и $1,6 \pm 0,3$ мккатал/л соответственно. Содержание малонового альдегида на 15 сутки от начала терапии у

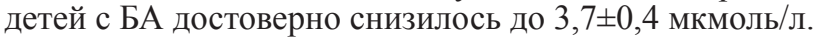

Содержание оксида азота в сыворотке крови больных бронхиальной астмой составило до лечения $6,1 \pm 0,16$ нмоль/мл, после терапии с применением азоксимера бромида 4,3 $\pm 0,21$ нмоль/мл (у здоровых детей $3,7 \pm 0,18$ нмоль/мл). Данные исследования биохимических показателей крови представлены в таблице 2.

Таблииа 2

Содержание иерулоплазмина, каталазы и малонового альдегида в сыворотке крови детей с бронхиальной астмой

\begin{tabular}{|l|l|l|l|}
\hline $\begin{array}{l}\text { नоказатели антиоксидантной } \\
\text { сисемы, ПОЛ }\end{array}$ & $\begin{array}{l}\text { Контроль-здоровые } \\
\text { дети }\end{array}$ & До лечения & После лечения \\
\hline Церулоплазмин, мг\% & $22,8 \pm 0,8$ & $15,9 \pm 0,8^{*}$ & $19,9 \pm 0,9^{* *}$ \\
\hline $\begin{array}{l}\text { Активность каталазы, } \\
\text { мккатал/л }\end{array}$ & $1,2 \pm 0,2$ & $0,8 \pm 0,1^{*}$ & $1,6 \pm 0,3^{* *}$ \\
\hline $\begin{array}{l}\text { Малоновый альдегид, } \\
\text { мкмль/л }\end{array}$ & $3,5 \pm 0,9$ & $5,4 \pm 0,3^{*}$ & $3,7 \pm 0,4^{* *}$ \\
\hline $\begin{array}{l}\text { Оксид азота (нитртиты), } \\
\text { нмоль/мл }\end{array}$ & $3,7 \pm 0,18$ & $6,1 \pm 0,16^{*}$ & $4,3 \pm 0,21^{* *}$ \\
\hline
\end{tabular}

Примечание: *- значение показателей, достоверно

отличающиеся от группы контроля; **- значение показателей, достоверно отличаючиеся от предыдущего этапа наблюдений при $p<0,05$

У больных с рецидивирующим бронхитом в период обострения содержание церулоплазмина и каталазы в сыворотке крови достоверно ниже, чем у здоровых детей и составило до лечения $17,9 \pm 0,7 \mathrm{M \Gamma} \%$ и $0,8 \pm 0,1$ ккатал /л соответственно, содержание малонового альдегида до лечения 4,8 $\pm 0,2$ мкмоль/л, что достоверно выше, чем у здоровых детей. После проведенного лечения содержание церулоплазмина и активность каталазы в

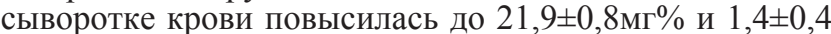
мккатал/л соответственно, содержание малонового альдегида на 15 сутки от начала терапии у детей с рецидивирующим бронхитом достоверно снизилось до 3,6 $\pm 0,2$ мкмоль/л.

Содержание оксида азота в сыворотке крови больных с рецидивирующим бронхитом составило до $6,2 \pm 0,24$ нмоль/мл, после терапии с применением азоксимера бромида 4,1 $\pm 0,22$ нмоль/мл (у здоровых детей $3,7 \pm 0,18$ нмоль/мл). Данные исследования биохимических показателей крови представлены в таблице 3.

Содержание иерулоплазмина, каталазы и Таблииа 3 малонового альдегида в сыворотке крови детей с рециидивирующим бронхитом

\begin{tabular}{|l|l|l|c|}
\hline $\begin{array}{l}\text { Показатели антиоксидантной } \\
\text { системы, ПОЛ }\end{array}$ & $\begin{array}{l}\text { Контроль-здоровые } \\
\text { дети }\end{array}$ & До лечения & После лечения \\
\hline $\begin{array}{l}\text { Lерулоплазмин, мг\%; } \\
\text { М } \pm \mathrm{m}\end{array}$ & $22,8 \pm 0,8$ & $17,9 \pm 0,7^{*}$ & $21,9 \pm 0,8^{* *}$ \\
\hline $\begin{array}{l}\text { А ктивность каталазы, } \\
\text { мккатал/л; } \mathrm{M} \pm \mathrm{m}\end{array}$ & $1,2 \pm 0,2$ & $0,8 \pm 0,2^{*}$ & $1,4 \pm 0,4^{* *}$ \\
\hline $\begin{array}{l}\text { Малоно оый альдегид } \\
\text { мкмоль/, } \mathrm{M} \pm \mathrm{m}\end{array}$ & $3,5 \pm 0,9$ & $4,8 \pm 0,2^{*}$ & $3,6 \pm 0,2^{* *}$ \\
\hline $\begin{array}{l}\text { Оксид азота (нитртиты), } \\
\text { нмоль млл }\end{array}$ & $3,7 \pm 0,18$ & $6,2 \pm 0,24^{*}$ & $4,1 \pm 0,22^{* *}$ \\
\hline
\end{tabular}

Примечание: *- значение показателей, достоверно

отличаюшиеся от группь контроля; **- значение показателей, достоверно отличающиеся от предыдущего этапа наблюдений при $p<0,05$

Таким образом, по содержанию церулоплазмина и активности каталазы можно судить об интенсивности антиоксидантной защиты, малонового альдегидаоб активности перекисного окисления липидов, оксида азота-о тяжести интоксикации организма до и после лечения с использованием полиоксидония. У детей с рецидивирующей бронхообструкцией в период обострения повышена активность перекисного окисления липидов и снижена антиоксидантная защита. В период клинического выздоровления при использовании базисной терапии в комплексе с иммуномодулятором наблюдается снижение продуктов ПОЛ и повышение показателей антиоксидантной защиты.

\section{СПИСОК ЛИТЕРАТУРЫ}

1. Баранов А.А. Детская аллергология. Руководство для врачей // М.: Геотар-Медиа, 2006. 100 с.

2. Хаптхаева г.Э. Обострение атопической бронхиальной астмы при респираторной инфекции: значимость респираторных возбудителей, системных биомаркеров, состояние гуморального и клеточного иммунитета // Аллергология. 2010. №2. С. 15-19.

3. Бронхиальная астма у детей. Стратегия лечения и профилактика. Национальная программа. 2-е издание. М.: Издательский дом «Русский врач», 2006. 100 с.

4. Романцов М.Г. Рациональная фармакотерапия часто болеющих детей: пособие для врачей. Под ред. М.Г. Романцова. Спб. 2006. 96 с.

5. Зиновьева Н.В., Давыдова Н.В., Щербина А.Ю., Продеус А.П., Румянцев А.Г. Часто болеющие дети: чем они больны на самом деле? //Трудный пациент. 2007. №2, Педиатрия. С. 25-27.

6. Ермолаева Е.В. Оптимизация лечения часто и длительно болеющих детей: иммунокоррекция препаратом Деринат// Медицинская кафедра. 2006. №3.C. 3-9.

7. Зубаренко А. В. Ключевые положения бронхиальной астмы у детей / А. В. Зубаренко, Т. В. Стоева, О. А. Портнова // Здоровье ребенка. 2006. №2.C. 82-86. 
8. Балаболкин И.И., Смирнов И.Е., Булгакова В.А. и др. Современная концепция патогенеза бронхиальной астмы у детей. // Иммунология, аллергология, инфектология. 2006. №1. С. 26-35.

9. Ильенкова Н.А. Оптимизация диагностики и лечения болезней органов дыхания у детей: Автореф. дис. д-ра мед. наук. Красноярск, 2007. 46 с.

10. Булгакова В.А., Балаболкин И.И., Сенцова Т.Б., Булгакова В.А., Рылеева И.В. Влияние вирусных инфекций на состояние гуморального и клеточного иммунитета у детей с аллергическими заболеваниями // Иммунология. 2005. №1. С. 21-25.

11.ДемкоИ.В.Клиническиеифармакоэкономические проблемы бронхиальной астмы / И.В. Демко, И.П. Артюхов // Первая краевая. 2008. №33. С. 19-26.

12.Балаболкин И.И., Сюракшина М.В., Тюменцева Е.С. Иммунокорригирующая терапия в комплексном лечении детей с аллергией // Лечащий врач. 2005. №7. С. 40-43.

13. Зайцева О.В. Бронхиальная астма и респираторные инфекции у детей// Медицинский совет. 2013. №1. C. 34-41.

14. Герасимов С.В. Перекисное окисление липидов и антиоксидантная защита при бронхиальной астме / С.В. Герасимов // Укр. мед. часопис. 2000. №1 (15). С. 86-91.

15. Балаболкин И.И. Лечение аллергических болезней у детей. / Под ред. И. И. Балаболкина.-М.:
«Медицинское информационное агенство», 2008.-352с.

16. Любицкий О.Б, Клебанов г.И., Дьяконова В.А. Изучение антиоксидантных свойств иммуномодулятора полиоксидония. //Иммунология. 2005. №4. С. 200-205.

17. Болотских В.И. Клинико-лабораторное обоснование использования дифференцированной иммунокоррекции в комплексном лечении бронхиальной астмы// Автореф. дисс. на соискание докт. мед наук.-2007. 48 c.

18. Шувалова Ю.В. Клинико-лабораторная эффективность полиоксидония в комплексной терапии синдрома рецидивирующей бронхиальной обструкции у детей / Ю. В. Шувалова, Т.Б. Ахвердиева, Н.Г. Герасимова, Е.Н. Коваленко, Т.Е. Чашина, Л.В. Зотова, В.А. Горбатов // Современные проблемы науки и образования. 2013. №2. www.science-education.ru/ 108-8968.

19. Захарова Л.И., Битоцкая Т.М., Мокина Н.А. Эффективность рибосомального иммунокорректора в профилактике обострений рецидивирующего обструктивного бронхита и бронхиальной астмы у детей// Вопросы современной педиатрии. Т. 4 . №5. 2005. С. 66-68.

20. Шальнева Т.В. Эффективность использования дерината в комплексной фармакотерапии рецидивирующего бронхита и пневмоний у детей// Автореф. дисс. на соискание канд. мед наук. 2009. 22 с.

(C) 2015

\title{
THE MEANING OF PEROXIDATION AND ANTIOXIDANT SYSTEMS IN THE PATHOGENESIS OF BRONCHIAL OBSTRUCTION
}

N.G. Gerasimova, doctor of medicine, professor of the pediatrics department Mordovia N.P. Ogarev State University, Saransk (Russia)

T.B. Akhverdieva, post-graduate student of the pediatrics department Mordovia N.P. Ogarev State University, Saransk (Russia)

Y.V. Shuvalova, post-graduate student of the pediatrics department Mordovia N.P. Ogarev State University, Saransk (Russia)

E.N. Kovalenko, candidate of biological sciences, associate professor of the normal physiology department with a course of medical biochemistry Mordovia N.P. Ogarev State University, Saransk (Russia)

V.A. Gorbatov, candidate of medical sciences, senior lecturer of the pediatrics department Mordovia N.P. Ogarev State University, Saransk (Russia)

\begin{abstract}
Annotation. the pathogenesis of several diseases of respiratory system, in particular recurrent obstructive bronchitis and bronchial asthma are founded on syndrome of bronchial obstruction. The study of the pathogenesis aspects of these diseases is essential to improve the efficiency of treatment and rehabilitation of patients. Patients with bronchial obstruction syndrome have imbalance between reactions of lipid peroxidation and antioxidant system with a significant damage to biological membranes at the cellular and subcellular level. Metabolic response in these patients have lower compensatory capacity, that leads to development of more severe forms of the disease. The analysis of the data obtained showed that prior to initiating therapy in children with recurrent obstructive syndrome was a decrease in antioxidant protection indicators (ceruloplasmin content and catalase activity in blood serum) and an increase in indicators of intoxication (malondialdehyde content in the blood serum). After the use of polyoxidonium in a complex therapy the patients showed a reliable increase in the content of ceruloplasmin and catalaza activity in the blood serum and decrease in the content of malondialdehyde in the blood serum. It was found that before treatment patients had an increase in the index of intoxication (nitric oxide), after the use of polyoxidonium in a complex therapy they had a significant reduction of nitric oxide in the blood serum.

Keywords: bronchial obstruction; bronchial asthma; recurrent bronchitis; lipid peroxidation; antioxidant protection; patients; therapy; biochemical parameters.
\end{abstract}

\section{УДК 504.054 \\ ОЦЕНКА КАЧЕСТВА ТЕРРИТОРИИ, ПРИЛЕГАЮЩЕЙ К ОАО «ЗАВОД БУРОВОГО ОБОРУДОВАНИЯ»}

(C) 2015

М.Ю. Гарицкая, кандидат биологических наук, доцент кафедры экологии и природопользования Оренбургский государственный университет, Оренбург (Россия)

А.И. Байтелова, кандидат технических наук, доцент кафедры экологии и природопользования Оренбургский государственный университет, Оренбург (Россия) Л.А. Пикус, студентка кафедры экологии и природопользования Оренбургский государственный университет, Оренбург (Россия)

К.А. Косачёва, студентка кафедры экологии и природопользования Оренбургский государственньй университет, Оренбург (Россия)

Аннотация. Почва, выполняя ряд важных функций, является геомембраной и влияет на протекание большинства процессов в биосфере. При этом геохимические процессы, происходящие в почвах, играют важную роль в судьбе загрязнителей, так как органическое вещество, контролируя их перераспределение в экосистеме 